\title{
Proveniência de arenitos da Formação Cerro da Angélica (Grupo Bom Jardim, Ediacarano do RS) na porção sul da sub-bacia Camaquã central e suas implicações tectônicas
}

\author{
Alexsandra Costa de Freitas Leitão ${ }^{1}$, Liliane Janikian', Renato Paes de Almeida, \\ Antonio Romalino Santos Fragoso-Cesar ${ }^{l} \&$ Felipe Torres Figueiredo ${ }^{l}$
}

\begin{abstract}
Resumo O presente trabalho apresenta um estudo da proveniência de arenitos da porção inferior da Formação Cerro da Angélica ( 605 Ma), unidade basal do Grupo Bom Jardim da Bacia Camaquã, aflorantes na região da Casa de Pedra, município de Bagé, RS, integrando análise de fácies e suas associações, a levantamentos estratigráficos de detalhe, com o objetivo de obter elementos adicionais para a compreensão do contexto tectônico e do caráter das falhas de borda da bacia durante a sedimentação da unidade. Foram diagnosticadas quatro associações de fácies em duas seções colunares: (i) depósitos distais de leques aluviais, (ii) depósitos de rios efêmeros (iii) depósitos proximais de leques aluviais, (iv) depósitos de campo de dunas eólicas e interdunas. A análise de proveniência microscópica revelou variações temporais nas proporções entre fontes graníticas e vulcânicas básicas ao longo da coluna estratigráfica. Nos depósitos de leque aluviais, a variação vertical é marcada por aumento da proporção de contribuição granítica, interpretada como resultado de progressiva denudação da cobertura vulcânica pré-existente e exposição do embasamento plutônico. Nos sistemas aluviais distais, alternam-se trechos com predomínio de cada um desses dois componentes, possivelmente em função de diferentes contribuições entre fontes proximais com aporte transversal ao eixo da bacia (relacionadas aos leques aluviais) e fontes distais relacionadas a transporte paralelo ao eixo da bacia. A presença de fragmentos derivados de rochas vulcânicas básicas ou intermediárias revela que houve atividade vulcânica antes da deposição da Formação Cerro da Angélica. Essa interpretação favorece o modelo de rift ativo para a evolução da Bacia Camaquã, pois a fase de maior distensão (representada pelo Grupo Bom Jardim) inicia-se com atividade vulcânica. A análise de proveniência realizada nas sucessões de leques aluviais sugere que não houve movimentação lateral entre a fonte e esses depósitos, confirmando as considerações sobre o caráter normal das falhas ativas durante a deposição do Grupo Bom Jardim.
\end{abstract}

Palavras-chave: Proveniência, Período Ediacarano, Grupo Bom Jardim, Bacia Camaquã.

\begin{abstract}
Provenance of sandstones from the Cerro da Angélica Formation (Bom Jardim Group, Ediacaran, Rio Grande do Sul State, Southern Brazil) in the southern Camaquã Central sub-basin and its tectonic implications. This paper presents provenance data from the lowermost sandstone deposits of the Cerro da Angélica Formation ( $605 \mathrm{Ma}$ ) of the Bom Jardim Group (Camaquã Basin), which crops out in the Casa de Pedra region, Bagé, Rio do Sul State, southern Brazil, integrated with sedimentary facies analysis, based on detailed description of columnar sections. This approach aims to determine the tectonic context and the sense of displacement of the basin-border faults during the deposition of the unit. Four facies associations were identified: (i) distal alluvial fan deposits, (ii) ephemeral stream deposits, (iii) proximal alluvial fan deposits and (iv) eolian dune field deposits. Microscopic provenance analysis revealed stratigraphic changes in the proportion of granitic and basic volcanic sources. In the case of the alluvial fan deposits, there is a progressive increase of the granitic contribution, which is interpreted as the result of a progressive denudation of the volcanic cover and ensuing exposure of the plutonic basement. In the distal alluvial deposits, there is an alternation between the two main sources, which is interpreted as a consequence of change in the contribution from proximal, border-fault derived detritus related to transversal alluvial systems and from distal sources fed by axial alluvial systems. The presence of basic or intermediate volcanic rocks as detritus in the basin reveals volcanic activity before the deposition of the Cerro da Angélica Formation. This interpretation corroborates the model of active rifting for the evolution of the Camaquã Basin, as the main extensional phase (Bom Jardim Group) begins with volcanic activity. The absence of provenance variations in the alluvial fan successions suggests that there was no sin-depositional strike-slip displacement between the source and the deposits, thus confirming previous models of normal faulting during the deposition of the Bom Jardim Group.
\end{abstract}

Keywords: Provenance, Ediacaran Period, Bom Jardim group, Camaquã Basin.

1- Instituto de Geociências, Universidade de São Paulo, São Paulo (SP), Brasil. E-mail: alexsandraleitao@gmail.com

2- Instituto de Astronomia, Geofísica e Ciências Atmosféricas, USP, São Paulo (SP), Brasil. E-mail: lijanikian@yahoo.com.br 
INTRODUÇÃ̃O A Bacia Camaquã apresenta depósitos sedimentares e vulcano-sedimentares de idade ediacarana a eocambriana que registram os eventos tectônicos ocorridos após os episódios colisionais da Orogenia Brasiliana na região centro-sul do Rio Grande do Sul. Dessa forma, a caracterização do contexto tectônico de formação da Bacia Camaquã implica em importantes questões para o entendimento da evolução da Província Mantiqueira entre $630 \mathrm{Ma}$ e $530 \mathrm{Ma}$.

O Supergrupo Camaquã (Fragoso-Cesar et al., 2000, 2003; Paim et al., 2002; Janikian et al., 2003) reúne todas as sucessões sedimentares e vulcano-sedimentares da bacia, sendo subdividido, a partir da base, nas seguintes unidades: Grupo Maricá, Grupo Bom Jardim, Formação Acampamento Velho, Grupo Santa Bárbara e Grupo Guaritas. O supergrupo aflora em três sub-bacias principais, denominadas Camaquã Ocidental, Central e Oriental, separadas por altos do embasamento alinhados na direção NNE-SSW (Fig. 1).

Alguns dos modelos utilizados na explicação do contexto tectônico da bacia consideram que diferentes unidades representam ciclos de subsidência distintos, causados por mecanismos tectônicos que evoluem de processos orogênicos para pós-orogênicos (e.g. Fragoso-Cesar, 1991; Gresse et al., 1996; Paim et al., 2002; Teixeira et al., 2004). A partir de 1992, estes modelos passaram a incorporar a idéia de origem sin-transcorrente para uma ou mais unidades superiores do Supergrupo Camaquã, conforme proposto por Oliveira \& Fernandes (1991, 1992) e Machado \& Sayeg (1992).

Trabalhos recentes, baseados em mapeamento de semi-detalhe das principais exposições do Supergrupo Camaquã e em análises de fácies, proveniência e paleocorrentes (Fragoso-Cesar et al., 2000, 2001, 2003; Almeida, 2001, 2005; Janikian, 2001, 2004; Fambrini, 2003; Janikian et al., 2003, Pelosi \& Fragoso-Cesar, 2003) assumem um modelo de bacia distensional, fundamentado no estilo de preenchimento, na distribuição espacial dos sistemas deposicionais e em análises de proveniência, que revelam ausência do padrão de migração lateral de áreas-fonte característico de bacias transcorrentes (Nielsen \& Sylvester, 1995).

A possibilidade de um contexto tectônico regional diferente para cada unidade da bacia implica na necessidade de obtenção de dados específicos para cada uma dessas unidades. Dentro dessa proposta, Almeida (2005) demonstrou, através de análises de paleotensões separadas por intervalo estratigráfico que, para as unidades posteriores ao Grupo Maricá, os ciclos de subsidência estão vinculados a episódios distensionais, sendo a tectônica transcorrente relacionada às discordâncias entre as unidades. A confirmação desse modelo por dados de proveniência, entretanto, concentra-se em sucessões dos Grupos Santa Bárbara e Guaritas (Fambrini, 1998 e 2003; Almeida, 2001 e 2005), apesar de dados preliminares confirmarem o mesmo padrão de ausência de migração lateral entre depósitos e fontes para a áreatipo do Grupo Bom Jardim (Janikian, 2004).

Com o objetivo de testar a hipótese de tectônica distensional sin-sedimentar para o Grupo Bom Jardim, o presente trabalho apresenta análise de proveniência de arenitos da Formação Cerro da Angélica, unidade basal do Grupo Bom Jardim (sensu Janikian et al., 2003), na porção sul da sub-bacia Camaquã Central, na região do Abrigo Casa de Pedra. Dessa forma, o presente trabalho contribui para a evolução dos conhecimentos sobre os eventos tectônicos e sua relação com os episódios de sedimentação na Bacia do Camaquã no intervalo de tempo entre 605 e $590 \mathrm{Ma}$, durante a deposição da Formação Cerro da Angélica (Janikian, 2004).

CONTEXTO GEOLÓGICO O embasamento do Supergrupo Camaquã aflora na porção centro-sul do Rio Grande do Sul e estende-se para o Uruguai, onde coberturas análogas também ocorrem. Esse embasamento é formado por estruturas relacionadas à Orogênese Brasiliana e pelo Cráton Rio de La Plata, aflorante no Uruguai e sudoeste do Rio Grande do Sul, subdividido em dois blocos separados pela zona de cisalhamento Sarandy del Yi: (i) Bloco Florida (sensu Fragoso-Cesar, 1991), designado Terreno Pedras Altas por Bossi \& Campal (1992); e (ii) Bloco Valentines (sensu Fragoso-Cesar, 1991), designado Bloco Taquarembó no Rio Grande do Sul por Naumann et al. (1984), e Terreno Nico Perez no Uruguai por Bossi \& Campal (1992). As estruturas brasilianas incluem um terreno intraoceânico acrescido no Neoproterozóico (Terreno Rio Vacacaí de Fragoso-Cesar, 1991; Bloco São Gabriel de Babinski et al., 1996) e um cinturão metamórfico neoproterozóico (Cinturão Dom Feliciano de Fragoso-Cesar, 1980). Volumosos corpos graníticos posteriores ao metamorfismo neoproterozóico afetam o Cinturão Dom Feliciano, incluídos no Batólito Pelotas (Fragoso-Cesar et al., 1986). Granitos associados ocorrem também em altos estruturais da Bacia do Camaquã, relacionados ao magmatismo do Grupo Bom Jardim e da Formação Acampamento Velho.

A posição estratigráfica do Supergrupo Camaquã sobre as sucessões deformadas e metamorfizadas durante os eventos orogênicos neoproterozóicos e sua localização sobre o limite entre dois domínios distintos do embasamento (Terreno Rio Vacacaí a oeste e Cinturão Dom Feliciano a leste) levou a maior parte dos autores a relacionar, de diferentes formas, a Bacia do Camaquã ao Ciclo Brasiliano.

A interpretação de Almeida (1969) para a origem do Supergrupo Camaquã enquadra-se em um modelo amplo de evolução de toda a "Plataforma Brasileira", no qual haveria um estádio de transição entre a fase orogênica propriamente dita e o estádio de estabilização representado pelas sinéclises intracratônicas. Esse estádio de transição seria caracterizado pela gradual atenuação da mobilidade tectônica, com a redução dos dobramentos e predomínio de movimentação por falhas. Nesse contexto, Almeida (1969) reconhece indícios da gradual estabilização na evolução da Bacia do Camaquã, sendo a então denominada Formação Maricá “(...) intensamente dobrada (sic)(...)" mas não metamorfizada, a unidade vulcânica (Grupo Bom Jardim), juntamente com a Formação Santa Bárbara, seriam ca- 

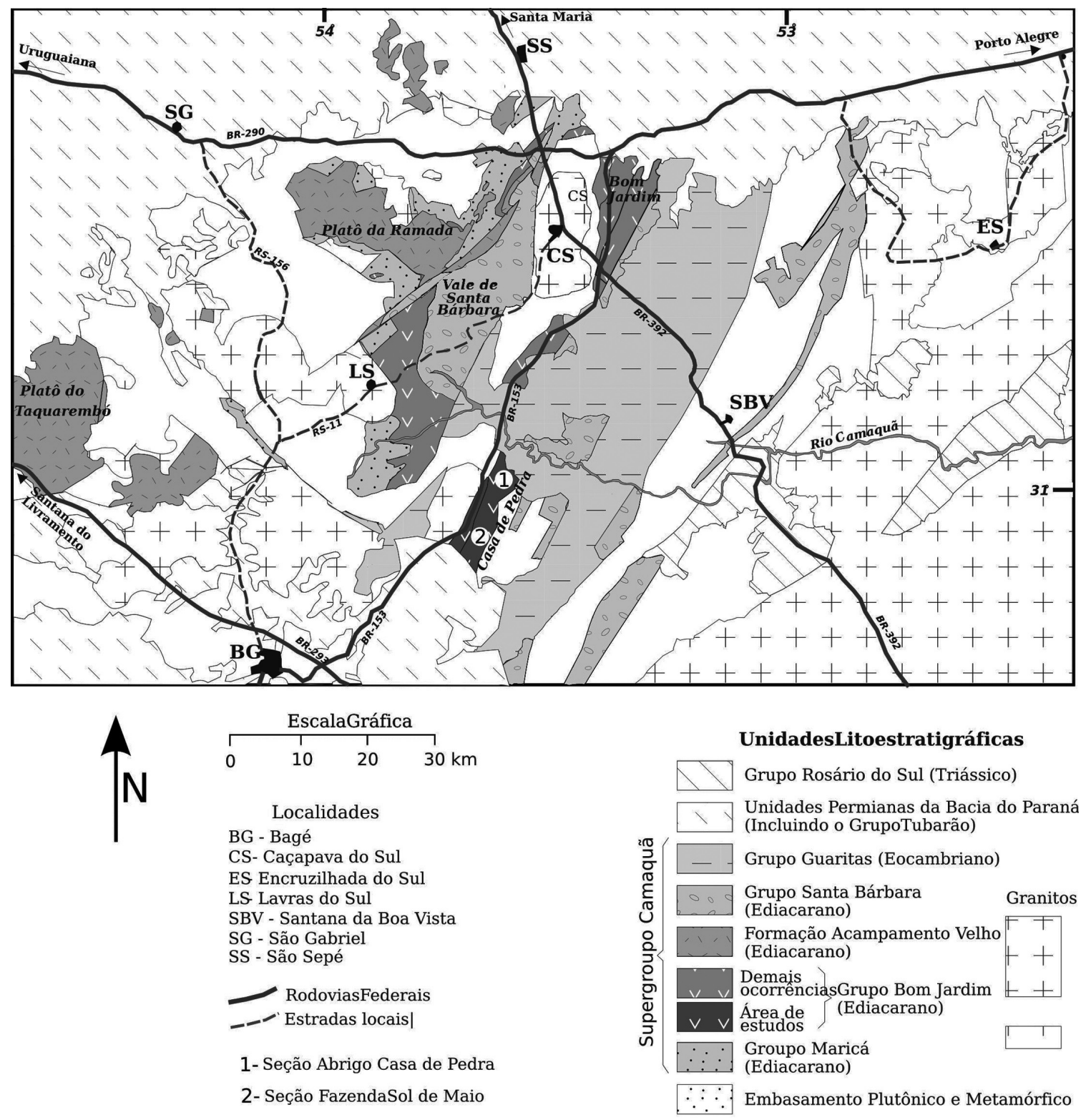

Figura 1 - Mapa geológico esquemático da Bacia Camaquã, com destaque para a área de estudo. Modificado de Almeida (2005).

racterizadas como molassas derivadas de áreas soerguidas por falhas, e a Formação Guaritas seria associada à atenuação da atividade tectônica.

Fragoso-Cesar et al. $\left(1982^{\mathrm{a}}, 1982^{\mathrm{b}}, 1984,1985\right)$ interpretaram as coberturas como o preenchimento de bacias de antepaís em um modelo baseado na tectônica de placas, relacionadas a espessamento crustal nos orógenos do tectonismo brasiliano. Fragoso-Cesar (1991) dividiu as coberturas da Bacia do Camaquã em dois conjuntos distintos: uma Antefossa Camaquã, preenchida pelo que hoje são consideradas as ocorrências orientais do Supergrupo Camaquã (Fragoso-Cesar et al., 2000); e uma bacia de retro-arco Santa Bárbara, incluindo as unidades sin- e pós-vulcânicas do Supergrupo Camaquã a oeste.

Beckel (1992) considerou uma evolução em diferentes tipos de bacias ao longo do tempo, sucedendo-se progressivamente bacias de antepaís, piggy-back, pull-apart e intra-montanas.

Gresse et al. (1996) associaram a evolução das coberturas do Rio Grande do Sul com as bacias tardi- à pós-orogênicas do sul da África, considerando uma bacia de retroarco de antepaís (sensu Ingersoll 1988) para as unidades pré e sin-vulcânicas, então denominadas grupos Maricá e Bom Jardim, e uma origem decorrente de colapso orogênico para as formações Santa Bárbara e Guaritas, agrupadas no Grupo Camaquã (sensu Robertson, 1966).

Uma outra tendência interpretativa passou a predominar nos anos 90, com a adoção de um modelo de bacias transcorrentes intracontinentais por Oliveira \& Fernandes (1991, 1992) e Machado e Sayeg (1992), baseados em trabalhos na Sub-Bacia Camaquã Oriental. Conclusão semelhante foi obtida por Brito Neves \& Cordani (1991), que consideraram um modelo regional controlado por tectônica de escape. Nesses modelos, as 
bacias seriam geradas por subsidência tectônica em regiões de afastamento dentro de zonas de cisalhamento transcorrentes tardi a pós-orogênicas. Paim et al. (2002) consideraram uma evolução policíclica para a bacia, incorporando o modelo transcorrente para as unidades posteriores ao Grupo Maricá.

Dados geoquímicos das rochas vulcânicas do Grupo Bom Jardim e da Formação Acampamento Velho, considerados em conjunto com os granitos contemporâneos, revelam altos teores de potássio e levam a distintos modelos. As rochas vulcânicas do Grupo Bom Jardim (Formação Hilário) foram interpretadas como produto de subducção, com caráter shoshonítico (e.g. Lima \& Nardi, 1985) ou magmas derivados de manto litosférico modificado por subducção anterior (Nardi \& Lima, 2002). As rochas da Formação Acampamento Velho foram tidas como orogênicas por Roisemberg et al. (1983), como de contexto pós-orogênico a anorogênico por Sommer et al. $\left(1995^{\mathrm{a}}, 1995^{\mathrm{b}}\right)$ e pós-orogênico por Wildner \& Nardi (1999), como magmatismo de afinidade alcalina tardi-orogênico por Nardi \& Lima (2002) e como magmatismo intra-placa pós-colisional por Wildner \& Nardi (2002).

A disparidade entre os modelos tectônicos para a Bacia do Camaquã reflete diferentes abordagens e a ausência de análises extensivas dos depósitos sedimentares em busca de informações relativas à caracterização tectônica. Trabalhos recentes, baseados em mapeamento de semi-detalhe das principais exposições do Supergrupo Camaquã e em análises de fácies, proveniência e paleocorrentes (Fragoso-Cesar et al., 2000, 2001, 2003; Almeida, 2001, 2005; Janikian, 2001, 2004; Fambrini, 2003; Janikian et al., 2003, 2005; Pelosi \& Fragoso-Cesar, 2003; Fambrini et al., 2005) assumem um modelo de bacias distensionais, fundamentado no estilo de preenchimento, na distribuição espacial dos sistemas deposicionais e em análises de proveniência, que revelam ausência do padrão de migração lateral de áreas-fonte característico de bacias transcorrentes (Nielsen \& Sylvester, 1995). O modelo adotado desvincula a Bacia do Camaquã da Orogenia Brasiliana, considerando o vulcanismo do Grupo Bom Jardim e da Formação Acampamento Velho como intraplaca, sem relação com arcos ativos, em concordância com os modelos geoquímicos mais recentes (e.g. Nardi \& Lima, 2002).

GEOLOGIA LOCAL A Formação Cerro da Angélica, definida por Janikian et al. (2003) aflora somente na sub-bacia Camaquã Central (Fig. 1). Na porção sul desta sub-bacia, região conhecida como Casa de Pedra, a Formação Cerro da Angélica apresenta uma espessura superior a $2.000 \mathrm{~m}$ (Fig. 2). Nesta localidade, Janikian (2004) subdividiu a formação nas seguintes unidades, a partir da base: (A) Arenitos Fluviais Inferiores, (B) Conglomerados de Enchentes em Lençol (de Leques Aluviais), (C) Arenitos Fluviais e Eólicos Superiores, (D) Arenitos de Frente deltaica e (E) Arenitos e Pelitos de Prodelta.

As pesquisas e análises apresentadas neste trabalho concentraram-se ao longo de 2 seções colunares de detalhe, correspondentes às unidades de arenitos so- topostos (A) e sobrepostos (C) aos depósitos conglomeráticos de leques aluviais (B), de Janikian (2004). A análise de fácies e de associações de fácies aqui apresentada levou a uma reinterpretação dos ambientes deposicionais destas sucessões areníticas. Estas análises foram integradas à coleta de 13 amostras para análise de proveniência, com posição estratigráfica definida.

A primeira seção corresponde à espessa sucessão arenítica sotoposta a depósitos de leques aluviais conglomeráticos (Fig. 3), aflorantes no Abrigo Casa de Pedra, com aproximadamente $580 \mathrm{~m}$ (seção 1). A segunda seção levantada corresponde a depósitos areníticos sobrepostos aos depósitos conglomeráticos de leques aluviais (Fig. 4), aflorantes na região da Fazenda Sol de Maio (seção 2). Esta sucessão apresenta aproximadamente $180 \mathrm{~m}$ de espessura (Janikian 2004) tendo sido detalhados $157 \mathrm{~m}$ do pacote.

MÉTODOS Para o desenvolvimento deste trabalho foram integrados diversos métodos e fontes de dados, incluindo fontes bibliográficas sobre a geologia local e regional, análises de proveniência macroscópica e microscópica, e análises de fácies. A aquisição de dados de campo contou com a descrição de afloramentos ao longo de perfis, levantamento de seções colunares, análise de fácies e de associações de fácies e a coleta de amostras para análises de proveniência microscópica.

O método aplicado para a análise de fácies foi baseado em Reading (1986), Walker (1992) e Miall (1990, 2000). As rochas constituintes do embasamento adjacente à região estudada foram descritas e classificadas para posterior comparação com os fragmentos encontrados nos arenitos e conglomerados da unidade estudada. A análise microscópica de proveniência de arenitos foi realizada com base no método Gazzi-Dickinson (Gazzi, 1966; Dickinson, 1970), com a contagem de 300 pontos por seção delgada e o registro não só da composição do fragmento observado, mas também do mineral constituinte (no caso de fragmentos líticos) correspondente ao ponto. Qualquer cristal e/ou grão, maior que 0,03 $\mathrm{mm}$, contido em fragmento lítico ou como grão em si foi considerado separadamente. Tal método apresenta a vantagem de compensar a influência da granulação na composição dos fragmentos, permitindo melhor avaliação comparativa entre diferentes amostras. $\mathrm{O}$ objetivo principal do método foi a reconstrução das composições detríticas originais, ao invés de ressaltar as alterações subseqüentes sofridas pelas rochas.

FÁCIES SEDIMENTARES Foi realizada a descrição das fácies sedimentares e a interpretação dos processos de transporte e deposição relacionados, o agrupamento de associações de fácies espacial e geneticamente relacionadas e, posteriormente, a interpretação dos sistemas deposicionais nas duas seções levantadas. Neste trabalho foram descritas e analisadas 10 fácies, posteriormente agrupadas em três associações de fácies na seção 1, levantada na região do Abrigo Casa de Pedra e outras três associações de fácies na seção 2 , próxima à Fazenda Sol de Maio. 


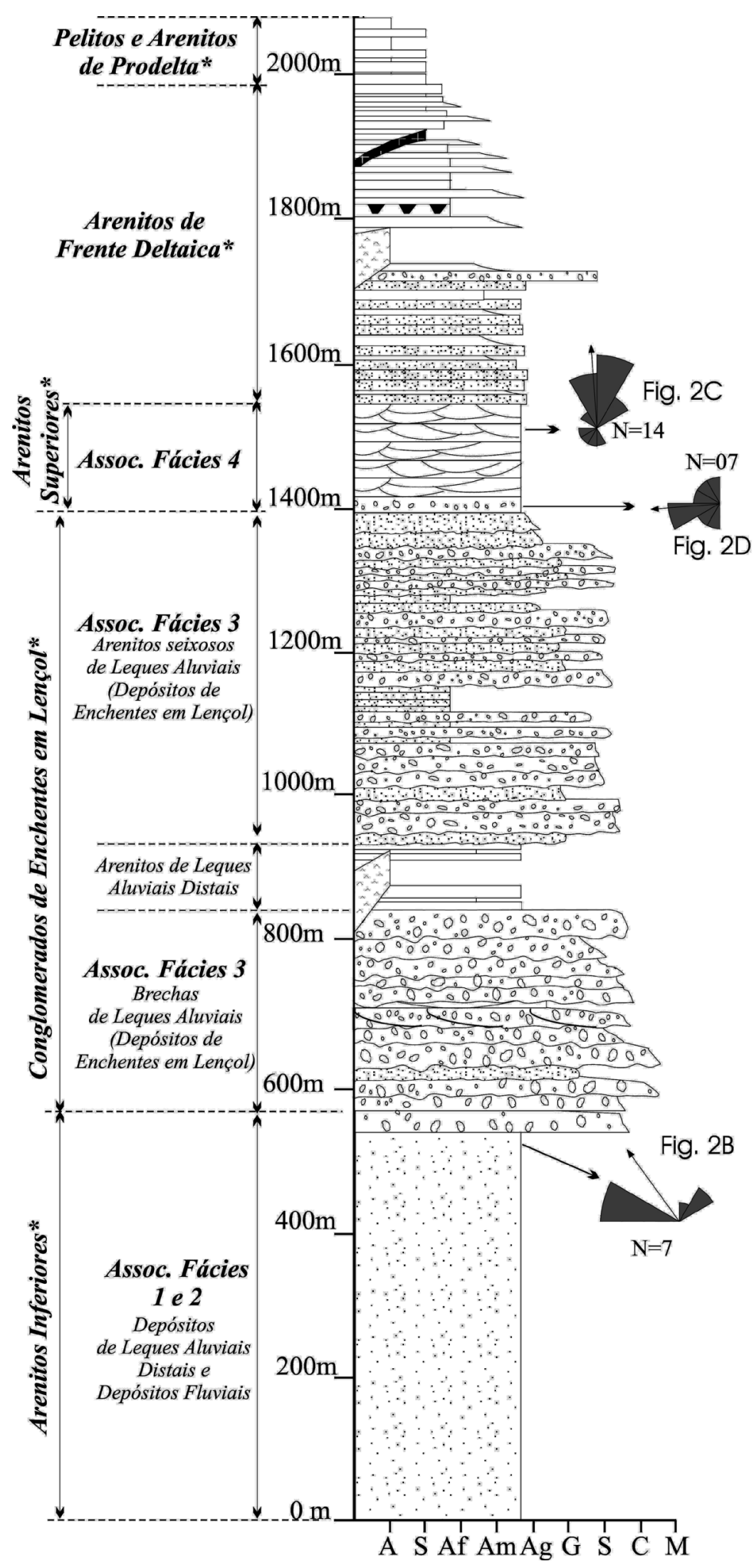

Legenda

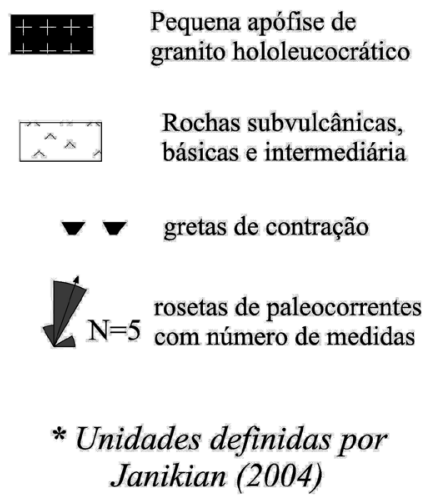

Seção Fazenda Sol de Maio

Assoc. Fácies 4:

Arenitos finos a médios eólicos de Depósitos de Dunas Barcanas e Arenitos seixosos de rios entrelaçados em áreas de Interduna

\author{
Assoc. Fácies 3: \\ Camadas Pareadas (conglomerados \\ e arenitos) de Leques Aluviais
}

\section{$\underline{\text { Seção Abrigo Casa de Pedra }}$}

Assoc. Fácies 3:

Camadas Pareadas (conglomerados e arenitos) de Leques Aluviais

Assoc. Fácies 2:
Arenitos seixosos de Rios Efêmeros

Assoc. Fácies 1:

Arenitos e Siltitos

de Leques Aluviais Distais

Figura 2 - Seção colunar das Associações de Fácies da Formação Cerro da Angélica aflorantes na região da Casa de Pedra, com direção de paleocorrentes da AF-2 (fig. 2B), paleoventos (fig. 2C) e de paleocorrentes (Fig. 2D) da AF-4. Modificado de Janikian (2004).

Arenitos finos com laminação plano-paralela (Al) e laminação cruzada de baixo ângulo (Alt)

DESCRIÇÃO Arenitos finos a médios, por vezes siltosos e micáceos, de coloração castanha avermelhada, com laminação plano-paralela (Al) (Fig. 5) ou laminação cruzada de baixo ângulo (Alt), dispostos em cama- das tabulares de 10 a $20 \mathrm{~cm}$ de espessura intercaladas ritmicamente com as fácies Sl e Alc. Localmente ocorrem em séries lenticulares, truncados por níveis de arenito médio maciço com intraclastos esparsos de pelito.

INTERPRETAÇÃO Depósitos de correntes trativas, 


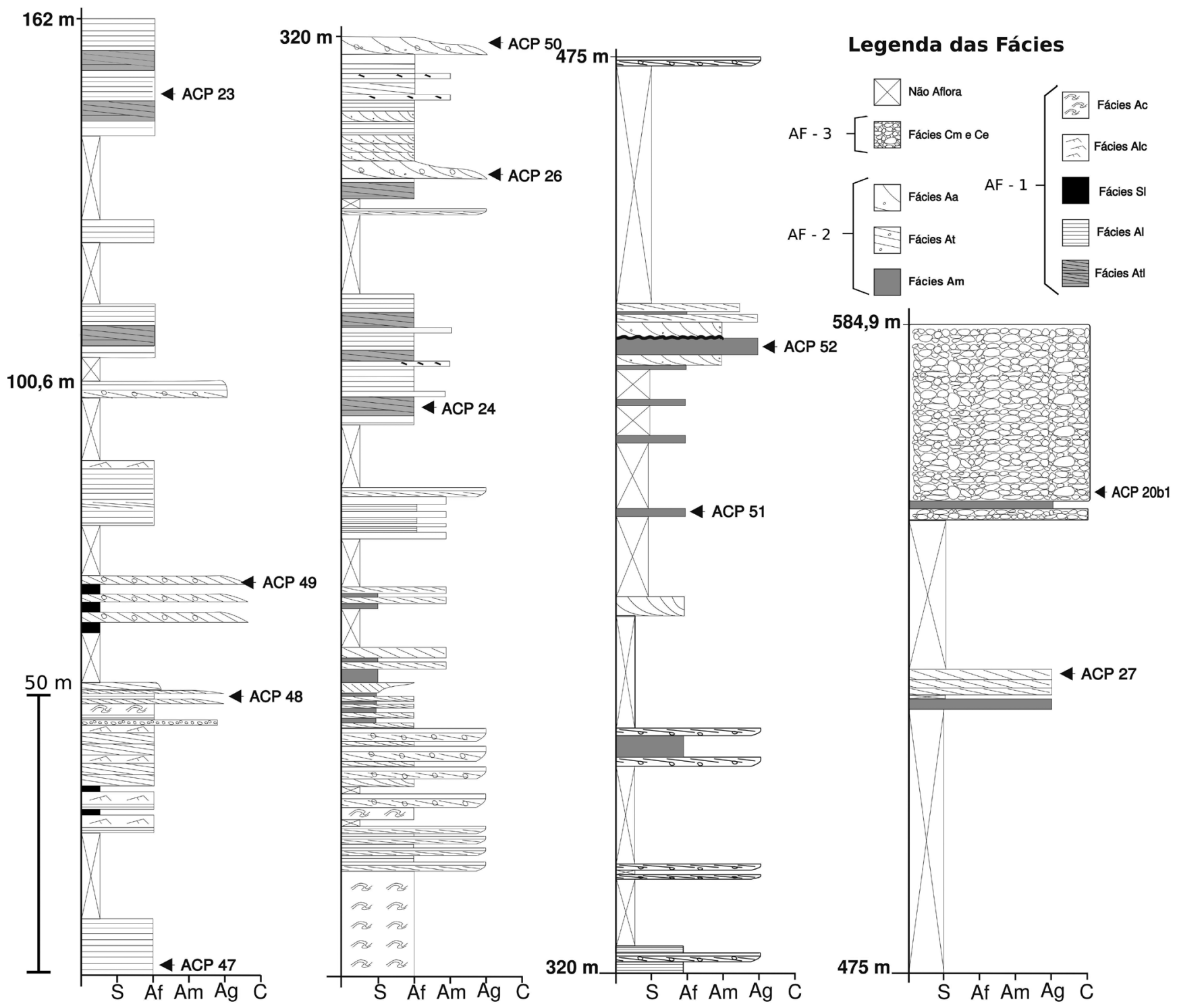

Figura 3 - Seção 1: seção colunar levantada nos depósitos de arenitos sotopostos aos depósitos conglomeráticos de Leques Aluviais da Formação Cerro da Angélica, na região do Abrigo Casa de Pedra.

em leito plano, possivelmente em regime de fluxo superior.

\section{Siltitos laminados (SI)}

DESCRIÇÃO Siltitos laminados (Fig. 5b), por vezes arenosos, de coloração marrom escura, dispostos em camadas lenticulares de até $10 \mathrm{~cm}$, em associação com as fácies Al e Alc.

INTERPRETAÇÃO Decantação de material em suspensão.

\section{Arenitos finos com laminação cruzada cavalgante (Alc)}

DESCRIÇÃO Arenitos finos com laminação cruzada cavalgante (Fig. 5c),, micáceos, de coloração castanhoavermelhada, dispostos em camadas tabulares de até 5 $\mathrm{cm}$. O cavalgamento das formas é geralmente supercrítico. Por vezes ocorrem níveis de arenito fino com laminação cruzada sem cavalgamento e com marcas onduladas no topo de cada série.

INTERPRETAÇÃO Depósitos de migração de marcas onduladas geradas por correntes trativas, com uma componente de deposição por decantação. O caráter supercrítico dos cavalgamentos demonstra uma grande contribuição de decantação, possivelmente por desaceleração de corrente trativa.

\section{Arenitos convolutos (Ac)}

DESCRIÇÃO Camadas tabulares, de espessuras centimétricas, de arenitos finos a médios de coloração marrom avermelhada, por vezes micáceos, com laminação convoluta, deformada em dobras abertas sem padrão. Ocorrem intercalados com a fácies Al, formando pacotes métricos que chegam a $4 \mathrm{~m}$ de espessura.

INTERPRETAÇÃO As feições de deformação são interpretadas como resultado de liquefação de sedimento, possivelmente obliterando a laminação da fácies Al. 


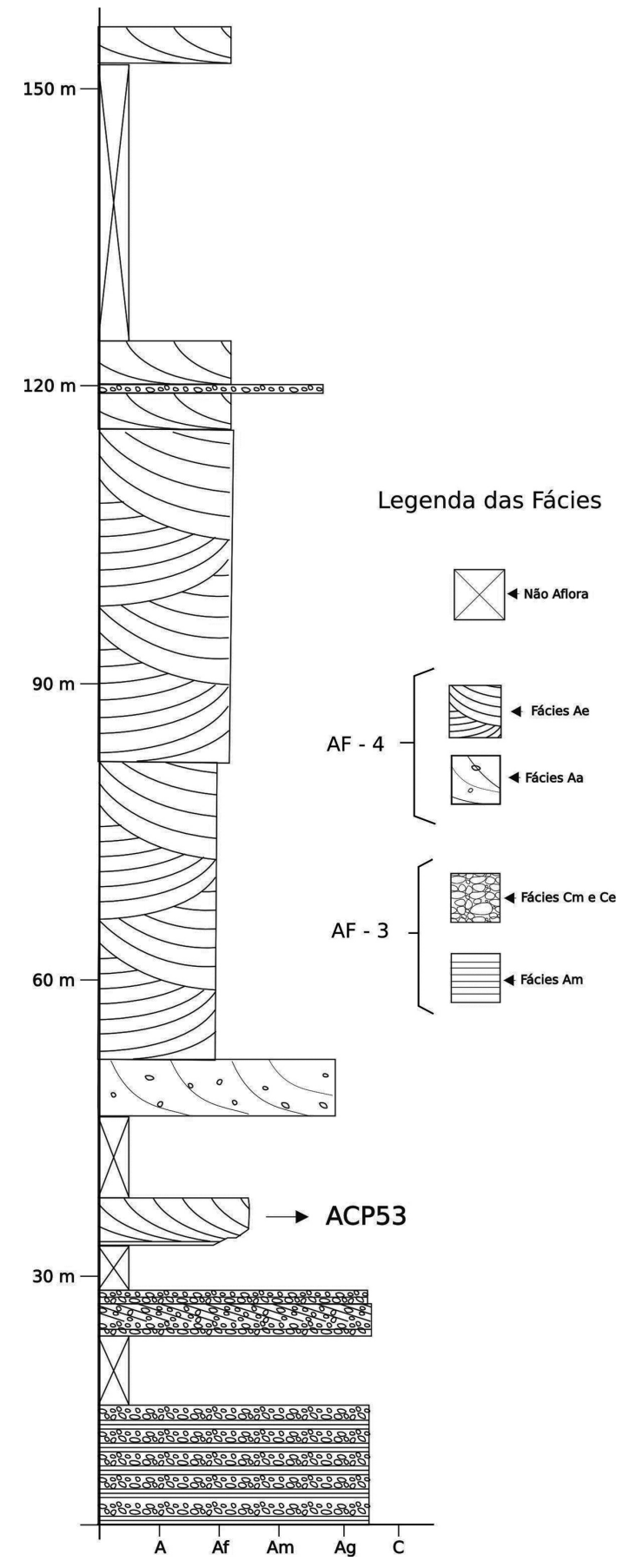

Figura 4 - Seção 2: seção colunar levantada nos depósitos de arenitos sobrepostos aos depósitos conglomeráticos de Leques Aluviais da Formação Cerro da Angélica, na região da Fazenda Sol de Maio.

\section{Arenitos com estratificação cruzada tabular (At)}

DESCRIÇÃO Arenitos médios a grossos com seixos esparsos, de coloração castanho escura, dispostos em camadas lenticulares decimétricas. Apresentam estratificação cruzada tabular. Apresentam granodecrescência em direção ao topo, passando para arenitos finos de laminação plano-paralela (fácies $\mathrm{Al}$ ) e arenitos com laminação cruzada (fácies Alc). A fácies Sl por vezes apresenta-se truncada ou erodida pela fácies At, que pode apresentar intraclastos da fácies $\mathrm{Sl}$ na base dos estratos.

INTERPRETAÇÃO Origem por migração de dunas subaquáticas de cristas retas em correntes trativas.

\section{Arenitos grossos maciços (Am)}

Descrição Arenitos grossos, por vezes com grânulos e seixos, de cor castanha, maciços, dispostos em camadas tabulares de $10 \mathrm{~cm}$ a 1 metro de espessura, que passam, em direção ao topo, para a fácies $\mathrm{Al}$ e, em seguida, para a fácies Alc com marcas onduladas no topo.

Interpretação Dois processos podem ser responsáveis pela formação desta fácies: aporte de correntes de turbidez em corpos d'água ou, deposição por fluxos de gravidade relacionados às porções distais de leques aluviais. A associação apenas com fácies de tração, sem depósitos de decantação expressivos, sugere deposição subaérea e favorece a segunda hipótese.

Arenitos com estratificação cruzada acanalada (Aa) DESCRIÇÃO Arenitos de granulação média a grossa, de cor marrom escura a clara, com estratificação cruzada acanalada em séries de espessuras decimétricas a métricas.

INTERPRETAÇÃO Origem por migração de dunas subaquáticas de cristas sinuosas em correntes trativas.

\section{Conglomerados maciços $(\mathbf{C m})$}

DESCRIÇÃO Conglomerados sustentados por fração arenosa de granulação média a fina, maciços, com seixos e calhaus (Fig. 5d). Algumas porções apresentam-se na fração areno-conglomerática, com seixos e calhaus esparsos.

INTERPRETAÇÃO Produto da sedimentação por fluxos de gravidade não coesivos.

\section{Conglomerados estratificados $(\mathrm{Ce})$}

DESCRIÇÃO Conglomerados de seixos, de cor variando de marrom clara a castanho escura, dispostos em camadas decimétricas com estratificação plano-paralela, marcada pela alternância entre níveis conglomeráticos e níveis arenosos laminados ricos em seixos e grânulos (Fig. 5e).

INTERPRETAÇÃO Possivelmente geradas por desestabilização de antidunas em regime de fluxo superior (camadas pareadas de enchentes em lençol sensu Blair, 1999).

Arenitos com estratificação cruzada acanalada de alto ângulo (Ae)

DESCRIÇÃO Arenitos finos a médios, de coloração marrom clara, dispostos em séries de estratificações cruzadas acanaladas (Fig. 5f), chegando a altos ângulos $\left(\sim 30^{\circ}\right)$, que variam de médio a grande porte (fácies Ae), com algumas camadas com estratificação de baixo 

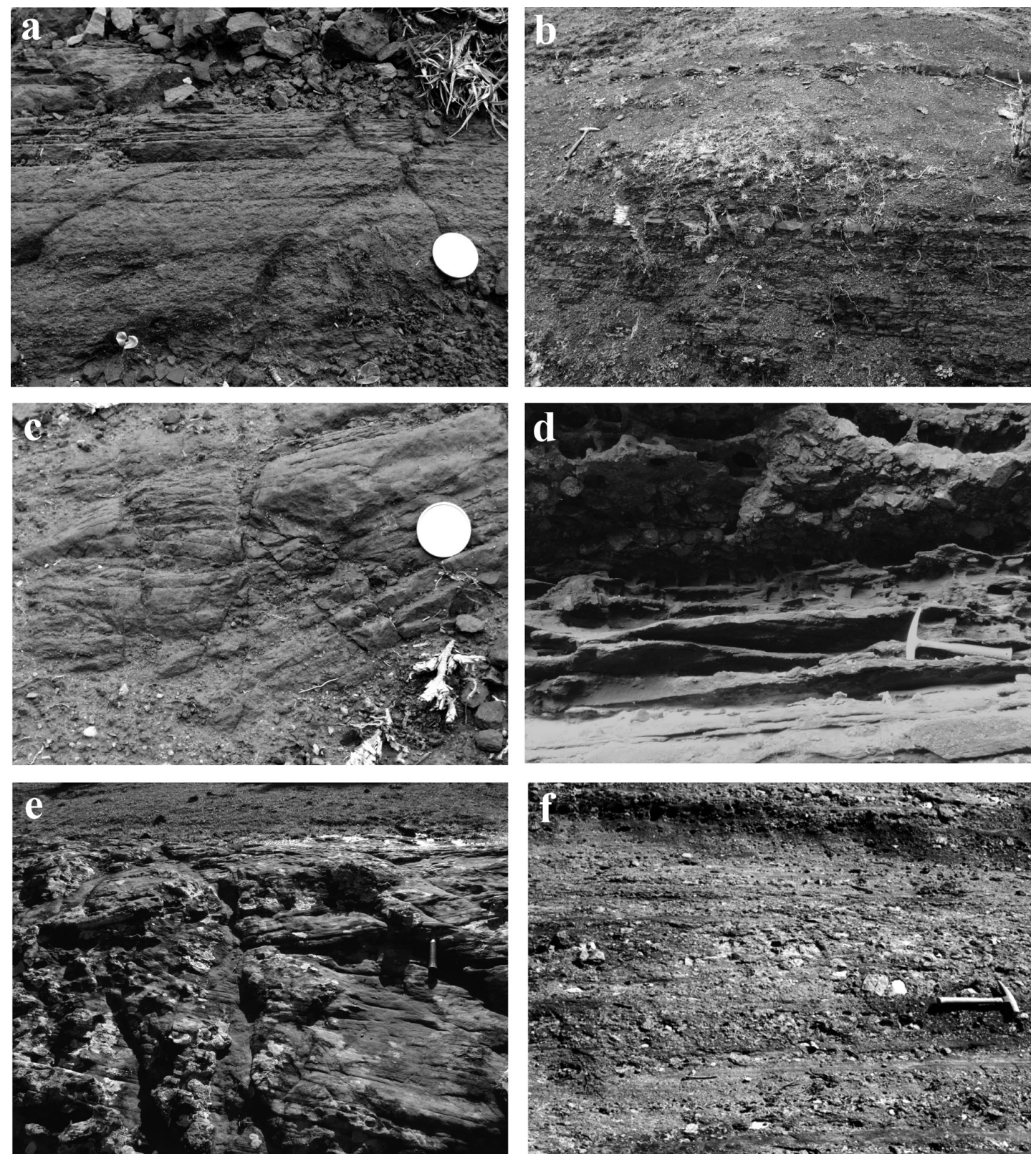

Figura 5 - Exemplos de fácies sedimentares da Formação Cerro da Angélica na região estudada. a- Fácies de arenitos finos com laminação plano-paralela (Al). b- Fácies de siltitos laminados (Sl). c- Fácies de arenitos finos com laminação cruzada cavalgante (Alc). d-Sucessão vertical de arenitos finos com laminação plano-paralela (Al) passando a arenitos com estratificação cruzada tabular (At) e por fim para conglomerados maciços (Cm). e- Fácies de conglomerado de seixos estratificado. $f$-Fácies de arenitos com estratificações cruzadas de grande porte de orgiem eólica (Ae).

ângulo. Estas fácies apresentam estruturas do tipo pinstripe (Fryberger \& Schenk, 1988) causada por alternância de níveis milimétricos maciços de granulação média e níveis laminados de granulação fina.

INTERPRETAÇÃO Migração de dunas eólicas barcanas ou cristas barcanóides. A intercalação entre níveis médios maciços e níveis finos laminados é devida à alternância entre deposição por fluxo de grãos e chuva de grãos, respectivamente (Hunter, 1977; Kocurek \& Dott, 1981).

\section{ASSOCIAÇÕES DE FÁCIES}

Seção 1 - Abrigo Casa de Pedra Uma espessa sucessão de arenitos, sotopostos aos depósitos conglomeráticos de leques aluviais, corresponde à sucessão mais basal da Formação Cerro da Angélica, aflorando somente na parte sul da Sub-bacia Camaquã Central. Essa sucessão corresponde à seção de detalhe levantada no abrigo Casa de Pedra, com cerca de $580 \mathrm{~m}$ de espessura (Figs. 2 e 3). Nesta seção foram identificadas três associações de fácies.

A primeira associação de fácies (AF-1) é composta por intercalações de camadas tabulares, de es- 
pessuras centimétricas a decimétricas, de arenito fino siltoso laminado (fácies $\mathrm{Al}$ ), arenito fino com climbing ripples (fácies $\mathrm{Alc}$ ) e siltito laminado (fácies $\mathrm{Sl}$ ), além de arenito médio maciço com intraclastos de pelitos (fácies Am). Intercalam-se camadas lenticulares de arenito fino com laminação cruzada de baixo ângulo (fácies Atl). Comumente as fácies Al e Atl passam para as fácies Alc e S1 no topo. Ocorrem ainda fácies de arenitos finos convolucionados (fácies Ac) indicando possivelmente alta taxa de sedimentação. As fácies areníticas de granulação fina e média que compreendem a AF-1 possivelmente correspondem às porções distais de leques aluviais, onde predomina fluxo desconfinado ou canalizado distributário.

A segunda associação de fácies (AF-2) compõe-se de camadas tabulares decimétricas de arenitos grossos maciços (fácies Am) e camadas lenticulares de arenitos grossos com estratificação cruzada tabular (fácies At) e acanalada (fácies Aa), que comumente intercalam-se ou erodem as fácies Al, Atl, Alc e Sl. Esta segunda associação de fácies sugere um ambiente fluvial, em função da presença das fácies de arenitos grossos com estratificação cruzada (fácies At), indicativos de correntes trativas em regime de fluxo inferior, que passam para o topo para arenitos finos com laminação plano-paralela (fácies Al), indicativos de tração em regime de fluxo superior (possivelmente por diminuição da lâmina d'água) e, por fim, para níveis centimétricos de arenitos com laminação cruzada (fácies Alc), sugestivos de atenuação de fluxo e perda de vazão. Essa ciclicidade da AF-2 sugere um ambiente de rios efêmeros com eventos de enchente seguidos por rápida diminuição da vazão, que poderiam estar associados à sistemas fluviais paralelos ao eixo da bacia.

A terceira Associação de Fácies (AF-3) compõe no topo da seção 1 e é caracterizada pelo predomínio de camadas tabulares decimétricas a métricas de conglomerados, de seixos e calhaus, maciços (Fácies Cm) e estratificados (Fácies Ce) e intercalações de arenitos grossos maciços (Fácies Am). Esta terceira associação de fácies foi interpretada por Janikian (2004) como depósitos de desestabilização antidunas geradas por processos de enchentes em lençol. Sucessões conglomeráticas semelhantes são descritas por Blair $(1987,1999)$, Blair and McPherson (1994), que analisaram com extremo detalhe as características deposicionais e texturais, além das principais fácies sedimentares, que são encontradas em depósitos de leques aluviais gerados por processos de enchentes em lençol, durante períodos de eventos catastróficos.

A AF-1 é comumente sobreposta pela AF-2, compondo um padrão progradacional ao longo da seção levantada na localidade do Abrigo Casa de Pedra. Isto é observado pela diminuição das espessuras das fácies de arenitos finos (fácies Alc) e siltosas (fácies Sl) e pelo aumento das espessuras (e freqüência) das camadas de arenitos grossos (fácies At e Aa) em direção ao topo, culminando com o aparecimento das camadas pareadas de conglomerados da AF-3.
ANÁLISE DE PALEOCORRENTES A análise de paleocorrentes obtida por Janikian (2004) nos arenitos com estratificação cruzada, predominantemente da AF-2, apresentou um paleofluxo para NW, com azimute para N324 (Fig. 2B). Esta direção foi interpretada como a direção aproximada do eixo da bacia, considerando que os sistemas fluviais longitudinais são os principais responsáveis pela entrada de sedimentos em uma bacia limitada por falhas (Leeder \& Gawthorpe, 1987; Gawthorpe \& Leeder, 2000). Fluxo transversal ao eixo da bacia em leques aluviais derivados de falhas de borda não foi identificado devido à escassez de estratificações cruzadas nas fácies que compõem as associações de fácies AF-1 e AF-3, porém sua ocorrência é provável.

Seção 2 - Fazenda Sol de Maio Foram diagnosticadas outras duas associações de fácies na seção de detalhe levantada na Fazenda Sol de Maio, porção centroleste da área (Fig. 4), que corresponde à sucessão de arenitos de sobrepõem os depósitos conglomeráticos de leques aluviais.

A base da seção apresenta um conjunto, de cerca de 30 metros de espessura, composto de camadas tabulares de espessuras decimétricas de conglomerados de seixos estratificados (fácies $\mathrm{Ce}$ ), pareadas com camadas tabulares de arenitos grossos, com seixos esparsos, maciços (fácies Am), e com estratificação plano-paralela (fácies Ae) e acanalada (fácies Aa), caracterizando domínio de fácies de camadas pareadas de conglomerados maciços e de arenitos seixosos estratificados, associados ao topo da AF-3, conforme proposta de Janikian (2004).

A quarta associação de fácies AF-4 ocorre de forma restrita na área, apresentando uma espessura variável de 0 a $180 \mathrm{~m}$ pois, tanto a AF-3 quanto a AF-4 encontram-se recobertas diretamente pelos depósitos deltaicos que predominam na porção intermediária da Formação Cerro da Angélica (Janikian et al., 2003; Janikian, 2004). Na AF-4 predominam camadas lenticulares (de espessuras decimétricas e comprimentos métricos) de arenitos finos com estratificação cruzada de alto ângulo (fácies Ae) interpretadas como produto de migração de dunas barcanas ou cristas barcanóides, em campo de dunas eólicas. Ocorrem também, nos primeiros $20 \mathrm{~m}$ da seção em questão, intercalações de camadas lenticulares, centimétricas a decimétricas, de arenitos grossos e arenitos seixosos, com estratificações cruzadas tabular (fácies At) e acanalada (fácies Aa), além de localmente estratificação plano-paralela (fácies Ap). Estas camadas possivelmente representam depósitos fluviais efêmeros de áreas de interdunas.

ANÁLISE DE PALEOCORRENTES A análise de paleocorrentes realizada nas fácies eólicas da AF-4 mostra um paleovento para $\mathrm{N}$, com azimute médio para N356 ${ }^{\circ}$ (Fig. 2B), o que poderia representar a direção aproximada do eixo da bacia, considerando-se que os sistemas fluviais longitudinais são os principais responsáveis pela entrada de sedimentos em uma bacia limitada por falha, segundo diversos autores (e.g. Leeder \& Gawthorpe, 1987). Também realizou-se análise de 
paleocorrentes nas fácies de interdunas, em camadas de arenitos seixosos angulosos com estratificação cruzada acanalada. O resultado obtido foi de paleofluxo para $\mathrm{W}$, com azimute do vetor médio para $\mathrm{N} 268^{\circ}$ (Fig. 2C), caracterizando um sistema transversal ao eixo da bacia para essas correntes intermitentes.

PROVENIÊNCIA DE ARENITOS Foram coletadas 13 amostras de rochas sedimentares ao longo das duas seções colunares descritas. Foi realizada a classificação segundo Folk (1968) e a contagem de 300 pontos por amostra em lâmina delgada pelo método Gazzi-Dickinson (Gazzi 1966, Dickinson 1970) para a interpretação da variação estratigráfica da proveniência dos depósitos da Formação Cerro da Angélica na área estudada.

Os fragmentos foram então agrupados de acordo com sua provável proveniência: Quartzo monocristalino com extinção homogênea, quartzo e/ou feldspato em fragmentos líticos graníticos e feldspato potássico tiveram sua proveniência associada à rochas graníticas/riolíticas. Plagioclásio e/ou fragmentos líticos de rochas vulcânicas básicas tiveram sua proveniência associada a rochas vulcânicas básicas. Quartzo policristalino e muscovita tiveram sua proveniência associada à rochas metamórficas. Fragmentos líticos de arenitos tiveram sua proveniência associada à rochas sedimentares. Biotita, opacos, quartzo microcristalino, quartzo monocristalino com extinção heterogênea, glauconita e clorita não tiveram sua proveniência determinada, assim como quartzo microcristalino, que pode ter tanto origem vulcânica (processo de devitrificação) como origem sedimentar (chert).

As porcentagens líticas/mineralógicas das frações arenosas das amostras coletadas nas duas seções levantadas neste trabalho são apresentadas na figura 6 .

Pode-se perceber, através da análise dos gráficos de proveniência microscópica, que ocorre uma franca contribuição de fontes ricas em plagioclásio e subordinadamente quartzo monocristalino com extinção homogênea em ambas as seções levantadas.

Contexto Tectônico interpretado a partir da Análise de Proveniência Uma forma convencional de análise de dados de proveniência é a interpretação do contexto tectônico da bacia com base nos diagramas propostos por Dickinson \& Suczek (1979). Esse método considera relações de proporção entre componentes detríticos para a caracterização do ambiente tectônico, com base em diagramas montados com dados de areias e arenitos de bacias com ambiente conhecido. Quatro diagramas são utilizados nessa caracterização: 1) quartzo-feldspatos-fragmentos líticos instáveis (QFL); 2) quartzo monocristalino - feldspatos - fragmentos líticos totais (QmFLt); 3) quartzo monocristalino - plagioclásio - feldspato alcalino (QmPK); 4) quatzo policristalino - fragmentos líticos vulcânicos - fragmentos líticos (meta)sedimentares (QpLvLs).

Os diagramas da figura 7 mostram os dados de contagem para a Formação Cerro da Angélica na região da Casa de Pedra. Como cada diagrama é elaborado com apenas alguns dos tipos de fragmentos contados, a soma total de componentes varia para cada diagrama.

No diagrama QFL (Fig. 7A), que se propõe a separar os tipos maiores de áreas-fonte, as amostras analisadas caem na região de transição entre uma proveniência imatura de blocos continentais soerguidos e uma proveniência de arcos magmáticos.

O diagrama QmPK (Fig. 7B) separa proveniências mais e menos maturas de blocos continentais e proporções entre contribuição plutônica e vulcânica para arcos magmáticos. As amostras analisadas caem em um campo de baixa maturidade e/ou maior contribuição vulcânica. A amostra mais matura (ACP53) corresponde a arenitos eólicos, possivelmente resultantes de retrabalhamento das areias aluviais.

O diagrama QpLvLs (Fig. 7C) distingue orógenos de arcos magmáticos de orógenos colisionais com base no conteúdo de fragmentos líticos. Para as amostras analisadas, esse diagrama apresenta uma resposta que contradiz os anteriores, devido principalmente à pequena quantidade de fragmentos líticos nas amostras. Por não considerar os feldspatos, principalmente plagioclásio que é abundante em todas as amostras, este diagrama indica uma proveniência de orógenos colisionais com base em pequenas quantidades de micas e fragmentos metassedimentares. Cabe ressaltar que o diagrama considera quartzo microcristalino como indicador de fonte metassedimentar (metachert), enquanto as amostras apresentam quartzo microcristalino como possível origem vulcânica (devitrificação).

O diagrama QmFLt detalha diferentes fontes de orógenos reciclados, podendo separar fontes com alto conteúdo de chert (como complexos de subducção) das demais fontes metassedimentares, não sendo, portanto, adequado para amostras com proveniência de blocos continentais ou arcos magmáticos.

A interpretação direta dos resultados dessa análise levaria à suposição de um ambiente de arco magmático com contribuição de embasamento denudado, porém com algumas discrepâncias, como um indício de maior contribuição plutônica no diagrama QFL e maior contribuição vulcânica no QmPK. Deve-se ressaltar que a interpretação proposta no trabalho original (Dickinson \& Suczek,1979) considera uma relação direta entre proveniência vulcânica e arcos magmáticos, possivelmente devido a uma particularidade na escolha dos dados utilizados na delimitação dos campos. Não foram utilizados, por exemplo, dados de bacias tipo rift (consideradas dentro do domínio de fontes de embasamento soerguido) em que há expressiva atividade vulcânica (não há dados das bacias do rift do leste da África). Assim, os campos de embasamento soerguido por falhas e de proveniência vulcânica (supostamente exclusiva de arcos) são claramente separados. Os dados do presente trabalho caem no limite entre os dois, onde possivelmente se encontram as bacias com fonte mista de embasamento soerguido e rochas vulcânicas, como os rifts com atividade vulcânica. 

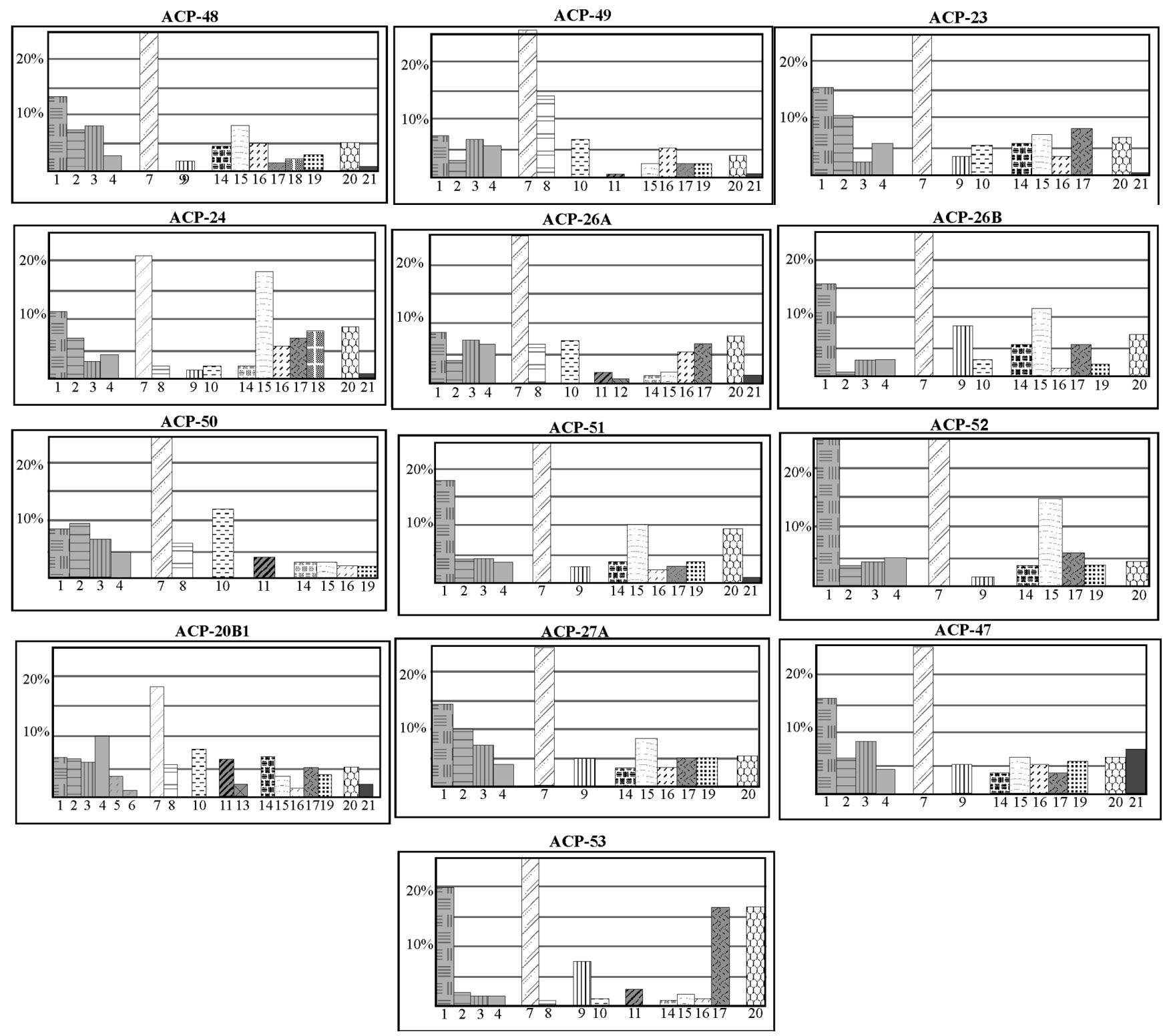

Figura 6 - Histogramas dos dados de contagem da proveniência de arenitos da Formação Cerro da Angélica na região da Casa de Pedra (sul da sub-bacia Camaquã Ocidental) resultantes da contagem de 300 pontos por lâmina. Fragmentos atribuidos a fontes graníticas-riolíticas: 1- quartzo monocristalino com extinção homogênea; 2- plagioclásio em fragmento lítico de granito; 3- quartzo em fragmento lítico de granito; 4-feldspato potássico; 5- feldspato potássico em fragmento lítico de granito; 6- biotita em fragmento lítico de granito. Fragmentos atribuídos a fontes vulcânicas básicas-intermediárias: 7- plagioclásio; 8-plagioclásio em fragmento lítico de andesito. Fragmentos atribuídos a fontes metamórficas:9- muscovita; 10- quartzo policristalino. Fragmentos atribuídos a fontes sedimentares: 11- quartzo em fragmento lítico de arenito; 12- feldspato em fragmento lítico de arenito; 13- biotita em fragmento lítico de arenito. Fragmentos de fonte desconhecida ou ambígua: 14- biotita; 15-opacos; 16- quartzo microcristalino; 17- quartzo monocristalino de extinção heterogênea; 18- glauconita; 19- clorita. Cimentos: 20-ferruginoso; 21 - carbonático.

Evolução Estratigráfica da Proveniência A análise estratigráfica da proveniência revela variações na proporção entre fontes vulcânicas e plutônicas ao longo da evolução da sucessão estudada. Duas falhas truncam a seção medida, porém, dada a escala da análise, seus rejeitos métricos não modificam a interpretação. De forma geral, a sucessão medida na seção 1 (Abrigo Casa de Pedra, Fig. 8) inicia-se com predomínio de contribuição vulcânica, com uma tendência gradual em di- reção à igualdade de proporção entre fontes graníticas/ riolíticas e vulcânicas básicas até os primeiros $200 \mathrm{~m}$. Um retorno gradual ao predomínio de vulcânicas básicas ocorre até aproximadamente $400 \mathrm{~m}$. Após os $400 \mathrm{~m}$, uma mudança brusca na proveniência leva a um predomínio de fontes graníticas/riolíticas, que é mantido até o topo da sucessão (Fig. 8).

Duas linhas de interpretação podem ser aplicadas a essa evolução: 1) a variação entre fontes vulcâni- 

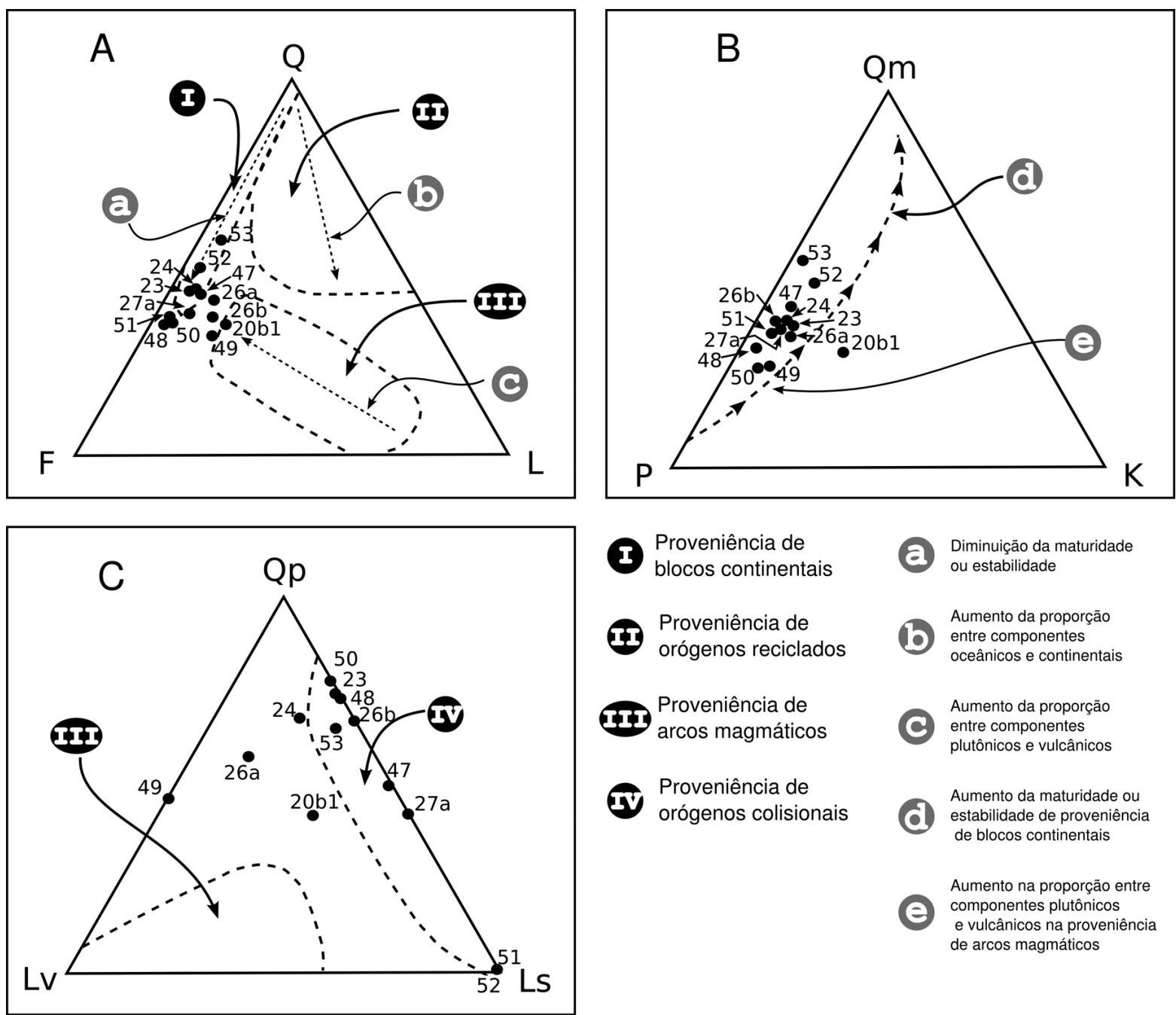

Figura 7 - Diagramas discriminantes de ambiente tectônico (Dickinson \& Suczek 1979) com dados obtidos para a Formação Cerro da Angélica na porção sul da sub-bacia Camaquã Central.

cas básicas e plutônicas graníticas reflete diferenças de nível de erosão das fontes, com a passagem de vulcânicas para plutônicas graníticas refletindo a progressiva erosão até o embasamento plutônico; 2) uma proveniência proximal trazida por transporte transversal ao eixo da bacia alterna-se com proveniência mais distal trazida por sistemas de transporte paralelos ao eixo da bacia.

A primeira hipótese pode explicar a variação inicial de fontes mais vulcânicas para um equilíbrio entre vulcânicas e plutônicas graníticas, porém não apresenta mecanismo possível para o efeito contrário que ocorre na continuidade da seção. A segunda hipótese poderia explicar a coincidência entre o aumento da proporção granítica no topo da sucessão e a instalação da associação de fácies de leques aluviais proximais (AF-3), implicando em um transporte transversal a partir de uma falha de borda que soergue granitos e um transporte axial que contribui com fontes vulcânicas nas regiões distais do sistema de leques. Dados de paleocorrentes confirmam a existência de transporte axial nas fácies fluviais da $\mathrm{AF}-2$, corroborando dados de paleocorrentes obtidos em outras ocorrências do Grupo
Bom Jardim por Janikian et al. (2003). A escassez de estratificações cruzadas nas fácies de leques aluviais não permite a comprovação de sua origem em sistemas transversais ao eixo da bacia, porém transporte fluvial foi reconhecido em fácies fluviais de interdunas, ortogonal à direção predominante de paleoventos (para N).

Assim, uma combinação dos dois mecanismos é sugerida como explicação para o padrão observado. Uma denudação inicial da cobertura vulcânica levaria ao aumento da proporção plutônica, sendo que fontes vulcânicas ainda estariam presentes em fácies distais com contribuição de transporte axial. $\mathrm{O}$ aumento da contribuição local com a progradação de leques aluviais levaria a um predomínio de fontes soerguidas pela falha de borda, no caso o embasamento granítico.

\section{Comparação com os litotipos aflorantes no embasa-} mento $\mathrm{O}$ embasamento adjacente à bacia é composto por rochas graníticas e metamórficas de baixo grau, não havendo resquícios de um vulcanismo anterior à Formação Cerro da Angélica. A análise de proveniência apresentada revela que houve atividade vulcânica bási- 


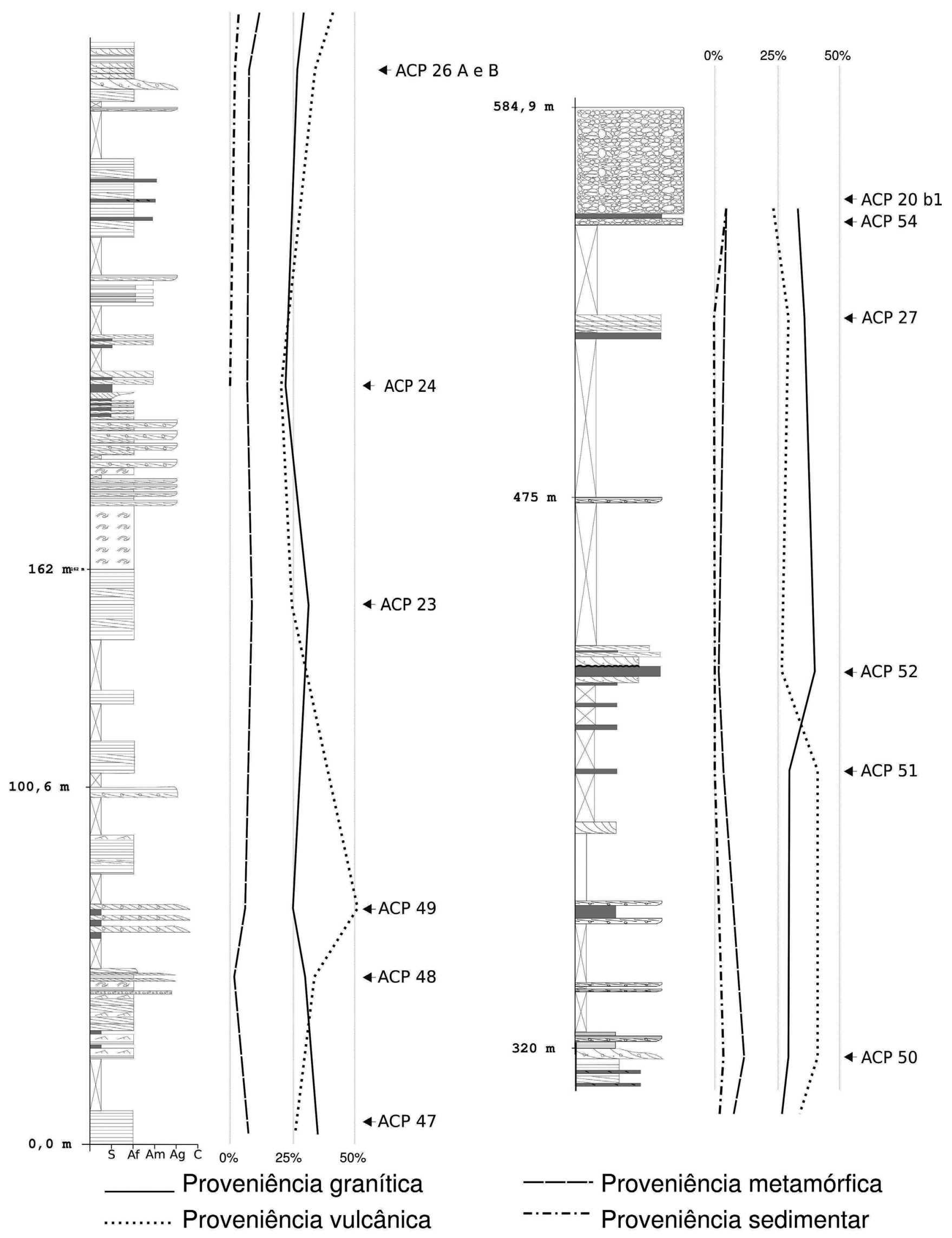

Figura 8 - Seção colunar levantada na porção inferior da Formação Cerro da Angélica integrada aos dados de proveniência separados em quatro tipos de áreas-fonte (granítica, vulcânica básica, metamórfica e sedimentar) (legenda ver Fig. 3). 
ca-intermediária e ácida, ao menos nas áreas soerguidas no entorno da bacia.

A componente do embasamento na proveniência dos depósitos estudados é quase exclusivamente granítica, principalmente nos depósitos de leques aluviais proximais, nos quais a fonte praticamente não varia por mais de 150 metros. Essa ausência de variação revela que não houve movimentação lateral relativa entre a fonte e os depósitos, pois nesse caso haveria modificações na contribuição relativa de diferentes litologias do embasamento. A avaliação quantitativa da proveniência macroscópica, realizada por Janikian (2004) nos depósitos de enchentes em lençol, revela a presença de fragmentos de feldspato alcalino superiores a $5 \mathrm{~cm}$, indicadores de fonte em um granito porfirítico. Como essa presença é constante em toda a sucessão, reforça-se a hipótese de movimentação predominantemente normal da falha de borda (sem o efeito esteira rolante esperado em falhas com movimentação transcorrente segundo Nielsen \& Sylvester, 1995). Por outro lado, a ausência desse litotipo na área hoje aflorante do embasamento revela que houve importante movimentação transcorrente pós-deposicional, possivelmente relacionada ao evento de deformação do limite Neoproterozóico-Cambriano descrito por Almeida (2005).

CONCLUSÕES O presente estudo buscou registrar a evolução da atividade tectônica e sua relação com a sedimentação da Formação Cerro da Angélica (Ediacarano do Rio Grande do Sul), através de análises de proveniência, análise e associação de fácies, empilhamento estratigráfico e paleocorrentes de duas seções colunares levantadas na região da Casa de Pedra, município de Bagé (RS).

Foram caracterizadas 10 fácies distribuídas em 4 associações de fácies, interpretadas como depósitos proximais e distais de leques aluviais, depósitos distais de rios efêmeros e depósitos de campo de dunas eólicas.

A sucessão é composta predominantemente por rochas arenáceas e rudáceas e as análises petrográficas indicam que as rochas arenáceas da sucessão em questão são arcóseos.

A análise de proveniência microscópica revela variações temporais na proporção entre fontes graníticas e vulcânicas básicas, com pequena quantidade de fontes metamórficas. No caso dos depósitos de leques aluviais, essa variação pode ser interpretada como resultado de modificações no nível de erosão dos altos, com a progressiva exposição do embasamento plutônico.

No caso dos sistemas distais, tanto de leques aluviais quanto de rios efêmeros, variações entre a proporção de vulcânicas e plutônicas pode ser resultado de diferentes contribuições entre fontes proximais tranversais ao eixo da bacia, a partir de falhas de borda, e fontes distais paralelas ao eixo da bacia.

A presença de fragmentos derivados de rochas vulcânicas básicas ou intermediárias revela que houve atividade vulcânica antes da deposição da Formação Cerro da Angélica, mesmo que somente nos altos adjacentes à bacia. Essa interpretação favorece o modelo de rift ativo para a evolução da Bacia Camaquã, proposto por Janikian (2004) e Almeida (2005), pois a fase de maior distensão (representada pelo Grupo Bom Jardim segundo Janikian, 2004) inicia-se com atividade vulcânica.

A ausência de variações de proveniência em diferentes níveis estratigráficos das sucessões de leques aluviais sugere que não houve movimentação lateral entre a fonte e os depósitos, pois nesse caso haveria modificações na contribuição relativa de diferentes litologias do embasamento. Por outro lado, a dificuldade de correlação entre as fontes hoje aflorantes na região e os fragmentos encontrados no depósitos indica que houve deslocamentos laterais pós-deposicionais. Esse modelo confirma as considerações de Janikian (2004) sobre o caráter normal das falhas ativas durante a deposição do Grupo Bom Jardim e estabelece o primeiro registro de eventos distensionais da Bacia Camaquã anteriormente reconhecido para os grupos Santa Bárbara (Fragoso-Cesar et al., 2001; Fambrini et al., 2001) e Guaritas (Almeida, 2005).

Agradecimentos Agradecemos à FAPESP pelo apoio na forma de bolsa de pós-doutoramento (processo $05 / 53522-8$ ) e de projetos de auxílio à pesquisa (processos 05/57939-9 e 06/50655-0). Ao Prof. Dr. Paulo César Fonseca Giannini pelos comentários e sugestões e aos geólogos Carlos Libório Tomba e Bruno Boito Turra pela participação nos trabalhos de campo. Agradecemos à detalhada revisão realizada pelo Prof. Dr. Paulo Sérgio Gomes Paim e pelo revisor anônimo.

\section{Referências}

Almeida F.F.M. 1969. Diferenciação tectônica da Plataforma Brasileira. In: SBG, Congresso Brasileiro de Geologia, 23, Salvador, Anais, v.1, p.29-46.

Almeida R.P. 2001. Evolução tectono-sedimentar da Formação Santa Bárbara na Sub-bacia Camaquã Ocidental, $R S$. Dissertação de Mestrado, Instituto de Geociências, Universidade de São Paulo, 160 p.

Almeida R.P. 2005. Tectônica e Sedimentação do Ediacariano ao Ordoviciano: Exemplos do Supergrupo Camaquã (RS) e do Grupo Caacupé (Paraguai Oriental). Tese de
Doutoramento, Instituto de Geociências, Universidade de São Paulo, 203p.

Babinsky M., Chemale Jr. F., Hartmann L.A., Van Schmus W.R., Silva L.C. 1996. Juvenile accretion at 750-700 Ma in southern Brazil. Geology 24(5):439-442.

Beckel J. 1992. Evolução tectônica da Bacia Camaquã, RS: proposta de classificação dentro de um conceito mobilista. In: SBG/UNISINOS, Workshop sobre as bacias molássicas brasilianas, 1, São Leopoldo, Boletim de Resumos Expandidos, p. 1-5. 
Blair T.C. 1987. Sedimentary processes, vertical stratification sequences and geomorphology of the Roaring River Alluvial Fan, Rocky Mountain National Park, Colorado. Journal of Sedimentary Petrology. 57:1-18.

Blair T.C. 1999. Sedimentary processes and facies of the waterlaid Amil Spring Canyon Alluvial Fan, death Valley, california. Sedimentology, 46:913-940.

Blair T.C. \& McPherson J.G. 1994. Alluvial fans and their natural distinction from rivers based on morphology, hydraulic, sedimentary processes, and facies assemblages. Journal of sedimentary research. 64(3):450-489.

Bossi J. \& Campal N. 1992. Magmatismo y tectónica transcurrente durante el Paleozoico Inferior en Uruguay. In: Marco Gutierrez J.G., Saavedra J., Rábano I. (eds.) Paleozóico Inferior de Ibero-America. Madrid, Universidad de Extremadura, p. 343-356.

Brito Neves B.B. \& Cordani U.G. 1991. Tectonic evolution of South America diring the Late Proterozoic. Precambrian Research, 53:23-40.

Dickinson W.R. 1970. Interpreting detrital modes of graywacke and arkose. Journal of Sedimentary Petrology, 40:695-707.

Dickinson W.R. \& Suczek C.A. 1979. Plate Tectonics and Sandstones Composition. The American Association of Petroleum Geologists Bulletin, 16(12):2164-2182.

Fambrini G.L. 1998. O Grupo Camaquã (Transição Proterozóico-Fanerozóico) na região das Minas do Camaquã, RS: análise estratigráfica de fácies, proveniência e paleocorrentes. Dissertação de Mestrado, IG-USP, São Paulo, SP, $182 \mathrm{p}$.

Fambrini G.L. 2003. O Grupo Santa Bárbara (Neoproterozóico III) da Bacia do Camaquã, Rio Grande do Sul. Tese de Doutoramento, IG-USP, São Paulo, 264p.

Fambrini G.L., Janikian L., Almeida R.P., Fragoso-Cesar A.R.S., 2005. O Grupo Santa Bárbara (Neoproterozóico III) na sub-bacia Camaquã Central, RS: sistemas deposicionais, paleogeografia e implicações tectônicas. Revista Brasileira de Geociências, 35:227-238.

Fragoso-Cesar A.R.S. 1980. O Cráton Rio de La Plata e o Cinturão Dom Feliciano no Escudo Uruguaio-Sul-Riograndense. In: SBG, Congresso Brasileiro de Geologia, 31, Camboriú, Anais, 5:2879-2892.

Fragoso-Cesar A.R.S. 1991. Tectônica de Placas no Ciclo Brasiliano: as orogenias dos Cinturões Dom Feliciano e Ribeira no Rio Grande do Sul. Tese de Doutoramento, IG-USP, São Paulo, SP, 366 p.

Fragoso-Cesar A.R.S., Almeida R.P., Fambrini G.L., Pelosi A.P.M.R., Janikian L. 2003. A Bacia Camaquã: um sistema intracontinental anorogênico de rifts do Neoproterozóico III-Eopaleozóico no Rio Grande do Sul. In: SBG, Encontro sobre a Estratigrafia do Rio Grande do Sul, 1, Porto Alegre, RS, Anais, vol. 1, p.139-144.

Fragoso-Cesar A.R.S., Faccini U.F., Paim P.S.G., Lavina E.L., Altamirano J.A.F. 1985. Revisão na estratigrafia das molassas do Ciclo Brasiliano no Rio Grande do Sul. In: SBG, Simpósio Sul-Brasileiro de Geologia, Florianópolis, 2, Anais, p.477-491.

Fragoso-Cesar A.R.S., Fambrini G.L., Almeida R.P., Pelosi A.P.M.R., Janikian L., Riccomini C., Machado R., Nogueira A.C.R., Saes G.S. 2000. The Camaquã extension- al basin: Neoproterozoic to early Cambrian sequences in southernmost Brazil. Revista Brasileira de Geociências, 30(3):438-441.

Fragoso-Cesar A.R.S., Fambrini G.L., Riccomini C., Janikian L., Almeida R.P., Pelosi A.P.M.R., Machado R. 2001. Estruturas induzidas por abalos sísmicos na Formação Santa Bárbara (Neoproterozóico III - Eocambriano), Bacia do Camaquã, RS: o exemplo do Passo da Capela. Revista Brasileira de Geociências 31(2):155-162

Fragoso-Cesar A.R.S., Figueiredo M.C.H., Soliani Jr. F., Faccini U.F. 1986. O Batólito Pelotas (Proterozóico Superior/ Eo-Paleozóico) no Escudo do Rio Grande do Sul. In: SBG, Congresso Brasileiro de Geologia, 34, Goiânia, Anais, v, 4, p.1322-1342.

Fragoso-Cesar A.R.S., Lavina E.L., Paim P.S.G., Faccini U.F. 1984. A Antefossa Molássica do Cinturão Dom Feliciano no Escudo do Rio Grande do Sul. In: SBG, Congresso Brasileiro de Geologia, 33, Rio de Janeiro, Anais, v.7, p. 3272-3283.

Fragoso-Cesar A.R.S., Wernick E., Soliani Jr. E. 1982a. Associações petrotectônicas do Cinturão Dom Feliciano (SE da Plataforma Sul-Americana). In: SBG, Congresso Brasileiro de Geologia, 32, Salvador, 1982. Anais, v. 1, p.1-12.

Fragoso-Cesar A.R.S., Wernick E., Soliani Jr. E. 1982b. Evolução geotectônica do Cinturão Dom Feliciano - Uma contribuição através da aplicação do modelo da Tectônica de Placas. In: SBG, Congresso Brasileiro de Geologia, 32, Salvador, 1982, Anais, v. 1, p. 13-23.

Fryberger S.G. \& Schenk C. J. 1988. Pin stripe lamination: a distinctive feature of modern and ancient eolian sediments. In: Hesp P. \& Fryberger S.G. (eds.) Eolian Sediments. Sedimentary Geology, 55:1-15.

Gawthorpe R.L. \& Leeder M.R. 2000. Tectono-sedimentary evolution of active extensional basins. Basin Research, 12:195-218.

Gazzi P. 1966. Le arenaire del flysch sopracretaceo dell Apennino Modenese; correlacione con il flysch di Monghidoro. Mineralogica e Petrografica Acta, 12:69-97.

Gresse P.G., Chemale F., Silva L.C., Walravens, Hartman L.A. 1996. Late- to post-orogenic basins of the Pan-African-Brasiliano collision orogen in southern Africa and southern Brazil. Basin Research, 8:157-171.

Hunter R. 1977. Basic types of stratification in small eolian dunes. Sedimentology, 24:361-387.

Ingersoll R.V. 1988. Tectonics of sedimentary basins. Geological Society of America Bulletin 100:1704-1719.

Janikian L. 2001. Evolução paleoambiental do Grupo Camaquã na região de Bom Jardim, Sub-Bacia Camaquã Central, RS. Dissertação de Mestrado, IGc-USP, São Paulo, SP, 158p.

Janikian L. 2004. Seqüências deposicionais e evolução paleoambiental do Grupo Bom Jardim e da Formação Acampamento Velho, Supergrupo Camaquã, Rio Grande do Sul. Tese de Doutoramento, IGc-USP, São Paulo, SP, 189p.

Janikian L., Almeida R.P., Fragoso-Cesar A.R.S., Fambrini G.L. 2003. Redefinição do Grupo Bom Jardim (Neoproterozóico III) em sua área-tipo: litoestratigrafia, paleogeografia e significado tectônico das sucessões vulcano- 
sedimentares do Supergrupo Camaquã, RS. Revista Brasileira de Geociências, 33:349-362.

Kocurek G. \& Dott R.H.Jr. 1981. Distinctions and uses of stratification types in the interpretation of eolian sands. Journal of Sedimentary Petrology 51(2):579-595.

Leeder M.R. \& Gawthorpe R.L. 1987. Sedimentary models for extensional tilt-block/half-graben basins. In: Coward M.P., Dewey J.F., Hancock P.L. (eds.) Continental extensional tectonics. Geological Society Special Publication, v. 28, p.139-152.

Lima E.F. \& Nardi L.V.S. 1985. Geologia, petrografia e petroquímica das rochas vulcânicas e tufáceas da região de Volta Grande, Lavras do Sul, RS. Acta Geologica Leopoldensia, 20:15-62

Machado R., Sayeg H.S. 1992. Aplicação da análise geométrica e cinemática nos falhamentos que condicionaram a bacia molássica do Arroio Boici, RS. In: SBG/UNISINOS, Workshop Sobre as Bacias Molássicas Brasilianas, 1, São Leopoldo, Boletim de Resumos Expandidos. 73-76.

Miall A.D. 1990. Principles of sedimentary basin analysis. $2^{\text {nd }}$ ed., New York, Springer-Verlag, 668 p.

Miall A.D. 2000. Principles of sedimentary basin analysis. $3^{\text {nd }}$ ed., New York, Springer-Verlag, 616 p.

Nardi L.V.S. \& Lima E.F. 2002. O magmatismo shoshonítico e alcalino da Bacia do Camaquã - RS. In: Holz M. \&. De Ros L.F. (eds.) Geologia do Rio Grande do Sul. p. 119-131.

Nardi L.V.S. \& Bitencourt M.F. 1989. Geologia, petrologia e geoquímica do Complexo Granítico de Caçapava do Sul. Revista Brasileira de Geociências, 19:153-169.

Naumann M.P., Hartmann L.A., Koppe J.C., Chemale Jr. F. 1984. Seqüências supracrustais, gnaisses graníticos, granulitos e granito intrusivos da região de Ibaré-Palma, RS - Geologia, aspectos estratigráficos e considerações geotectônicas. In: SBG, Congresso Brasileiro de Geologia, 33, Rio de Janeiro. Anais, v.5, p. 2417-2425.

Nielsen T.H.\& Sylvester A.G. 1995. Strike-Slip Basins. In: Busby C.J. \& Ingersoll R.V. (eds.) Tectonics of Sedimentary Basins. Blackwell Science, p. 425-457.

Oliveira J.M.M.T. \& Fernandes L.A.D. 1991. Estágios finais da evolução do Cinturão Dom Feliciano: Tectônica e sedimentação da Formação Arroio dos Nobres. In: SBG, Simpósio Nacional de Estudos Tectônicos, 3, Rio Claro, Boletim de Resumos Extensos, p.58-59.

Oliveira J.M.M.T. \& Fernandes L.A.D. 1992. Bacias molássicas brasilianas, mito ou realidade? In: SBG/UNISINOS, Workshop Sobre as Bacias Molássicas Brasilianas, 1, São Leopoldo, Boletim de Resumos Expandidos, p.97105

Paim P.S.G., Chemale Jr. F., Lopes R.C. 2002. A Bacia do Camaquã. In: Holtz M. \& DeRos L.F. (eds.) Geologia do Rio Grande do Sul, CIGO/UFRGS, p. 231-274.
Pelosi A.P.M.R. \& Fragoso-Cesar A.R.S. 2003. Proposta litoestratigráfica e considerações paleoambientias sobre o Grupo Maricá (Neoproterozóico III), Bacia do Camaquã, Rio Grande do Sul. Revista Brasileira de Geociências, 33:137-148.

Reading H.G. 1986. Facies. In: Reading H.G. (ed.) Sedimentary Environments and Facies. $2^{\text {nd }}$ edition, Oxford, Blackwell, p. 4-19.

Robertson J.F. 1966. Revision of Stratigraphy and nomenclature of rock units in Caçapava-Lavras Region. Notas $e$ Estudos, IG-UFRGS, Porto Alegre, 1(2):41-54

Roisenberg A., Loss E.L., Altamirano J.A.F., Ferreira A.C. 1983. Aspectos petrológicos e geoquímicos do vulcanismo Pré-cambriano - Eopaleozóico do Rio Grande do Sul com base nos elementos maiores. In: Simpósio Sul-Brasileiro de Geologia, 1, Porto Alegre, RS, Atas, p. 271-285.

Sommer C.A., Lima E.F., Nardi L.V.S. 1995ª Faciologia da seqüência vulcânica ácida do Platô do Taquarembó, Dom Pedrito-RS. In: SBG, Simpósio Sul-Brasileiro de Geologia, 4 / Encontro de Geologia do Cone Sul, 1, Porto Alegre, Boletim de Resumos, p. 200-201.

Sommer C.A., Lima E.F., Nardi L.V.S. 1995b. Considerações vulcanológicas sobre a seqüência vulcânica ácida do Platô do Taquarembó - Dom Pedrito, RS. In: SBG, IV Simpósio Sul-Brasileiro de Geologia, 4, / Encontro de Geologia do Cone Sul, 1, Porto Alegre, Boletim de Resumos, p. 202-204.

Teixeira A.L., Gaucher C., Paim P.S.G., Fonseca M.M., Parente C.V., Silva Filho W.F., Almeida A.R. 2004. Bacias do Estágio da Transição da Plataforma Sul-Americana. In: Mantesso Neto V., Bartorelli A., Carneiro C.D.R., Brito Neves B.B. (eds.) Geologia do Continente SulAmericano: Evolução da Obra de Fernando Flávio Marques de Almeida. Beca, p. 487-537.

Walker R.G. 1992. Facies, facies models and modern stratigraphic concepts. In: Walker R.G. \& James N.P. (eds.) Facies Models and Response to Sea-level Change 1-14. Geological Association of Canada Geotext 1, p.1-14.

Wildner W. \& Nardi L.V.S. 1999. Caracterísitcas geoquímicas e petrogenéticas do vulcanismo neoproterozóico do Sul do Brasil - Platô do Taquarembó - RS. In: Simpósio sobre vulcanismo e ambientes associados, 1, Boletim de resumos, p. 30.

Wildner W. \& Nardi L.V.S. 2002. Caracterísitcas geoquímicas e de posicionamento tectônico do magmatismo neoproterozóico aflorante no Platô do Taquarembó - RS. Revista Brasileira de Geociências, 32(2):169-184.

Manuscrito AE 072-2006

Submetido em 12 de fevereiro de 2007 Aceito em 01 de dezembro de 2007 